\title{
Limbic Encephalitis Associated with Primary Biliary Cirrhosis
}

\author{
Hortensia Alonso-Navarro ${ }^{a}$ Rosario Martín ${ }^{a}$ José Antonio Arenas ${ }^{a}$ \\ Félix Javier Jiménez-Jiméne $z^{\text {b }}$ \\ a Sección de Neurología, Hospital Universitari 'Sant Joan d'Alacant', Alicante, and b Departamento de \\ Medicina-Neurología, Hospital 'Príncipe de Asturias', Universidad de Alcalá, Alcalá de Henares (Madrid), Spain
}

Dear Sir,

The first descriptions of patients with possible limbic encephalitis (LE) were made by Charatan and Brierley in 1956 [1] and Brierley et al. in 1960 [2]. However, the term 'limbic encephalitis' as a clinicopathological entity was not coined until 1968 by Corsellis et al. [3]. LE affects the mesial temporal lobes and limbic mesial cortical structures and is clinically characterized by subacute onset of short-term memory impairment, personality changes, seizures and autonomic nervous system disorders. Up to a few years ago, 200 cases of LE had been reported, most of them associated with lung cancer and more infrequently with other tumors; however, it is likely that this syndrome is underrecognized [4-7].

Although traditionally LE has been considered to be a paraneoplastic syndrome, its etiological spectrum has recently been extended after the description of cases related with viral infections (especially herpes simplex), autoimmune diseases, or idiopathic LE associated with high titers of antibodies to voltage-gated potassium channels (VGKC) $[5,7]$. Early detection of antineuronal or other specific antibodies such as anti-VGKC or antiglutamate receptor $\varepsilon 2$ antibodies, and detection of neurotropic viral genomes in the CSF by PCR are important for a correct differential diagnosis. Although complete recovery of higher cerebral functions is difficult, early treatment with acyclovir, vitamin B, immunotherapy and antiepileptic drugs has been recommended [7].
We report a patient diagnosed with primary biliary cirrhosis well-controlled with treatment, who developed bilateral LE with a good therapeutic response to intravenous corticosteroids.

\section{Case Report}

The patient was a 45-year-old nonsmoking woman with a previous history of fibromyalgia. She was diagnosed 2 years ago with primary biliary cirrhosis by liver biopsy, and was treated with ursodeoxycholic acid, with good control. She had been examined by the Internal Medicine Department because of a 6-month history of recurrent fever that she had related with a trip to Bolivia, and was diagnosed with fever of unknown origin after appropriate diagnostic studies.

The patient was admitted to hospital because of an increase in fever $\left(38.5^{\circ} \mathrm{C}\right)$ and a generalized tonic-clonic seizure. General examination was normal except for the presence of low-grade fever $\left(37.4^{\circ} \mathrm{C}\right)$. Neurological examination showed an important impairment of remote memory, and even more marked of recent memory, temporal disorientation and mild psychomotor agitation. She was able to recall 5 digits in the direct sense and only 3 in the inverse sense. Visuoperceptive and visuospatial memory, ideatory, ideomotor and constructional praxis, gnosias, insight and judgement were all normal.

Blood count, erythrocyte sedimentation rate, routine biochemistry and urinal- ysis, serum or plasma levels of vitamin $B_{12}$, folic acid, $\mathrm{C}_{3}, \mathrm{C}_{4}, \mathrm{~T}_{3}, \mathrm{~T}_{4}, \mathrm{TSH}$, and lactate were normal. Blood and urine cultures, Giemsa-stained blood smears, and stool analysis looking for parasites were negative. Serologic studies for syphilis, Brucella, HIV, Borrelia, Mycoplasma pneumoniae, and herpes simplex viruses, and the Paul Bunnell test were negative. Serum IgG for the herpesviruses varicella-zoster and cytomegalovirus was slightly positive. Antinuclear, anti-Ro, anti-La, antithyroid, antiLKM, anti-Hu, anti-Yo, anti-Ri, anti-Tr, anti-Ma2, anti-amphiphysin, anti-CVS/ CRMP-5, and anti-VGKC antibodies, and tumor markers (Ca 19.9, CEA 4.2, Ca 125, $\alpha$-fetoprotein) were negative. Antimitochondrial and antismooth muscle antibodies were positive at titers $>1 / 160$ and $>1 / 80$, respectively. ECG, chest radiography, mammography, vaginal smear with culture, gynecological ultrasonography, and thoraco-abdomino-pelvic CT scan were normal.

Brain CT scan was normal as well. Electroencephalogram showed diffuse slowing and bilateral asymmetric paroxysmal activity consistent with spike or acute waves in medial temporal regions, which was more marked on the left side. Brain MRI showed hyperintense lesions in both hippocampi in FLAIR (fig. 1a) and $\mathrm{T}_{2}$-weighted images, which did not enhance with gadolinium. Angiographic MRI was normal. Brain PET showed bilateral frontotemporal hypometabolism, more marked on the right side, and whole-body PET scan was normal.

\section{KARGER}

Fax +4161306 1234 E-Mail karger@karger.ch www.karger.com
(C) 2006 S. Karger AG, Basel 0014-3022/06/0553-0174\$23.50/0

Accessible online at: www.karger.com/ene
Hortensia Alonso-Navarro Paseo de Canalejas $21,2^{\circ} \mathrm{C}$ ES-37001 Salamanca (Spain) Tel. +34 67983 5277, Fax +34913280704

E-Mail hortalon@yahoo.es 
Routine CSF analysis showed 4 leukocytes/ $\mathrm{mm}^{3}$, glucose $72 \mathrm{mg} / \mathrm{dl}$, and protein 31.9 $\mathrm{mg} / \mathrm{dl}$. PCR for herpes simplex virus types 1 and 2, Epstein-Barr virus, and cytomegalovirus, serologic studies for Borrelia and Brucella, and cytological studies in the CSF were negative.

A diagnosis of idiopathic LE was made, and the patient was treated with valproic acid $900 \mathrm{mg} /$ day, thiamine $100 \mathrm{mg} / 8 \mathrm{~h}$, acyclovir $750 \mathrm{mg} / 8 \mathrm{~h}$, and 3 cycles of intravenous methylprednisolone (1 g/day for 5 days) at the diagnosis and after 2 and 4 months. Recent and remote memory impairment improved slightly, while attentional deficit and temporal disorientation did not improve. A brain MRI performed 7 months after diagnosis showed bilateral hippocampal atrophy (fig. 1b).

\section{Discussion}

Paraneoplastic LE has been reported in association with various tumors. Approximately $50 \%$ of paraneoplastic LE are associated with lung carcinoma, both oat cell and other histological types, $20 \%$ are associated with testicular carcinoma and $8 \%$ with breast cancer [4]. Cases associated with immature ovarian teratoma [8], Hodgkin's lymphoma $[9,10]$ and malignant thymoma $[11,12]$ have also been reported. Most of these patients, up to $60 \%$, showed positivity of onconeuronal antibodies [4]. The following antibodies were most frequently positive: anti-Hu antibodies $[4,7]$, with positivity rates up to $50 \%$ in cases with LE associated with lung carcinoma of the oat cell type [13], antibodies against P/Q-type voltagedependent calcium channels [14], anti-Tr antibodies in patients with Hodgkin's disease associated with cerebellar degeneration or LE [9], and anti-Ta or anti-Ma2 antibodies in a patient with LE and breast cancer [15] and in patients with testicular tumors [4]. Onconeuronal antibodies were frequently negative in patients with LE and lung cancer other than oat cell type [13].

Currently, anti-VGKC antibodies are considered to be important to differentiate 'pure' autoimmune LE from paraneoplastic LE. These antibodies have been detected in the serum of patients with neuromyotonia - which frequently coexists with thymoma or autoimmune diseases such as myasthenia gravis - and in such patients, the risk for development of LE seems to be higher [16-19], but with a better prognosis [17]. In addition, in the serum and CSF of patients with ataxia, LE and some types of epilepsy, the existence of antibodies against calcium
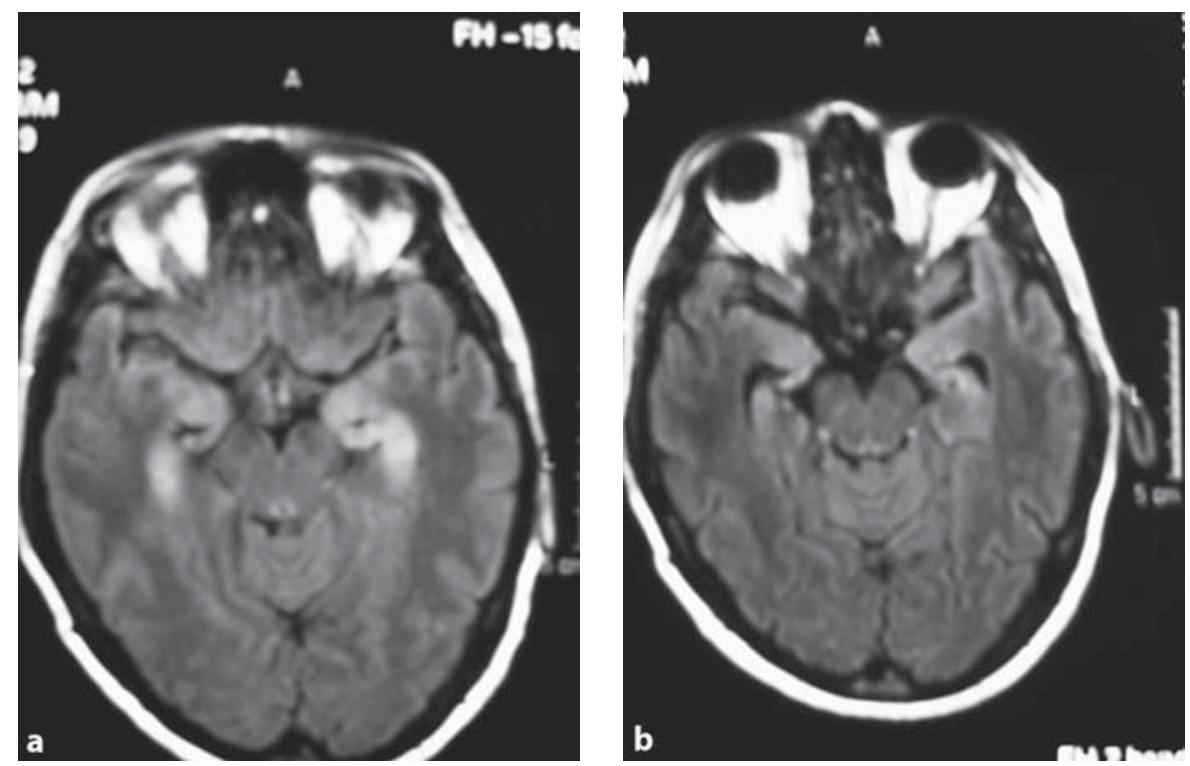

Fig. 1. Brain MRI (FLAIR-weighted images). a Hyperintense lesions in both hippocampi at the diagnosis of LE, which did not enhance with gadolinium. b Bilateral hippocampal atrophy 7 months thereafter.

channels and glutamate receptors has been described. The presence of these antibodies, together with the good therapeutic response to immunotherapy, could suggest that they might have a pathogenetic role [19].

Primary biliary cirrhosis is a liver autoimmune disease of unknown etiology. Autoimmune attack is organ specific despite the presence of mitochondrial autoantigens, which are the main target of autoimmunity in this disease in all nucleated cells [20]. Primary biliary cirrhosis has been reported to be associated with Sjögren's syndrome and transverse myelitis [21, 22], with mitochondrial encephalomyopathy [23] and with sensory neuropathy $[24,25]$.

In our patient, the diagnosis of autoimmune LE was made after a reasonable exclusion of possible infectious or paraneoplasic etiologies of LE syndrome. However, despite the patient being a nonsmoker, the short time of follow-up does not allow ruling out the possibility of a paraneoplastic LE, because the tumor may appear 2-3 years after the diagnosis of LE $[4,26]$. Although, to our knowledge, there are no previous reports of primary biliary cirrhosis associated with LE, the coincidence of two diseases of possible autoimmune origin in the same patient would suggest the existence of a relationship between them.
To date, only a few patients have been reported with LE associated with autoimmune diseases after excluding a paraneoplastic origin. The autoimmune disease most frequently reported in association with LE (MRI was usually normal) is Hashimoto's thyroiditis [27-30]. Nakajima et al. [31] reported a patient with left mesial temporal encephalitis including hippocampal affectation with increased titers of antinuclear and anti-SSA/Ro antibodies and increased CSF IgG levels and IgG index. Morita et al. [11] described LE, opsoclonus myoclonus and sensorimotor and autonomic neuropathy in a patient with Addison disease and malignant thymoma. The association of LE with malignant thymoma has also been reported by Evoli et al. [12]. Finally, Stubgen [32] described a patient with LE and increased CSF titers of antiribosome $\mathrm{P}$ antibodies, suggesting its association with CNS lupus erythematosus.

Most authors suggest that, in the absence of evidence of neoplastic or infectious disease, treatment with a combination of plasmapheresis and intravenous immunoglobulins improves the clinical outcome and decreases the MRI abnormalities [33]. Other authors recommend the use of intravenous steroid boluses (methylprednisolone $1 \mathrm{~g}$ /day for 5 days) repeated monthly for 3 months and, in refractory cases, intravenous immunoglobulins and plasmapheresis [7]. 


\section{References}

1 Charatan FB, Brierley JB: Mental disorder associated with primary lung carcinoma. $\mathrm{Br}$ Med J 1956;1:765-768.

2 Brierley JB, Corsellis JAN, Hierons R, et al: Subacute encephalitis of later adult life mainly affecting the limbic areas. Brain 1960;83:357368.

3 Corsellis JA, Goldberg GJ, Norton AR: 'Limbic encephalitis' and its association with carcinoma. Brain 1968;91:481-496.

4 Gultekin SH, Rosenfeld MR, Voltz R, Eichen J, Posner JB, Dalmau J: Paraneoplastic limbic encephalitis. Neurological symptoms, immunological findings and tumour association in 50 patients. Brain 2000;123:1481-1494.

5 Inuzuka T: Limbic encephalitis: etiology, pathogenesis, diagnosis and therapy. Rinsho Shinkeigaku 2004;44:799-801.

6 Pearce JMS: Paraneoplastic limbic encephalitis. Eur Neurol 2005;53:106-108.

7 Graus F, Sáiz A: Encefalitis límbica: un síndrome probablemente infradiagnosticado. Neurología 2005;20:24-30.

8 Stein-Wexler R, Wootton-Gorges SL, Greco CM, Brunberg JA: Paraneoplastic limbic encephalitis in a teenage girl with an immature ovarian teratoma. Pediatr Radiol 2005;35: 694-697.

9 Bernal F, Shams'ili S, Rojas I, et al: Anti-Tr antibodies as markers of paraneoplastic cerebellar degeneration and Hodgkin's disease. Neurology 2003;60:230-234.

10 Werbrouck B, Meire V, De Bleecker JL: Multiple neurological syndromes during Hodgkin lymphoma remission. Acta Neurol Belg 2005; 105:48-50.

11 Morita H, Hirota T, Mune T, et al: Paraneoplastic neurologic syndrome and autoimmune Addison disease in a patient with thymoma. Am J Med Sci 2005;329:48-51.
12 Evoli A, LoMonaco M, Marra R, Lino MM, Batocchi AP, Tonali PA: Multiple paraneoplastic diseases associated with thymoma. Neuromuscul Disord 1999;9:601-603.

13 Chen Q, Li Q, Qian W, Tang Q, Liu X: Immunologic and clinical study of paraneoplastic limbic encephalitis. Zhongguo Yi Xue Ke Xue Yuan Xue Bao 1998;20:466-469.

14 Hiasa Y, Kunishige M, Mitsui T, et al: Complicated paraneoplastic neurological syndromes: a report of two patients with small cell or nonsmall cell lung cancer. Clin Neurol Neurosurg 2003; 106:47-49.

15 Sutton I, Winer J, Rowlands D, Dalmau J: Limbic encephalitis and antibodies to Ma2: a paraneoplastic presentation of breast cancer. Neurol Neurosurg Psychiatry 2000;69:266268.

16 Newsom-Davis J: Neuromyotonia. Rev Neurol (Paris) 2004;160:85-89.

17 Thieben MJ, Lennon VA, Boeve BF, Aksamit AJ, Keegan M, Vernino S: Potentially reversible autoimmune encephalitis with neuronal potassium channel antibody. Neurology 2004; 62:1177-1182.

18 Newsom-Davis J, Buckley C, Clover L, Hart I, Maddison P, Tuzum E, Vincent A: Autoimmune disorders of neuronal potassium channels. Ann NY Acad Sci 2003;998:202-210.

19 Lang B, Dale RC, Vincent A: New autoantibody mediated disorders of central nervous system. Curr Opin Neurol 2003;16:351-357.

20 Kita H, He XS, Gershwin ME: Autoimmunity and environmental factors in the pathogenesis of primary biliary cirrhosis. Ann Med 2004; 36:72-80.

21 Anantharaju A, Baluch M, Van Thiel DH: Transverse myelitis occurring in association with primary biliary cirrhosis and Sjögren's syndrome. Dig Dis Sci 2003;48:830-833.

22 Rutan G, Martinez AJ, Fieshko JT, Van Thiel DH: Primary biliary cirrhosis, Sjögren's syndrome, and transverse myelitis. Gastroenterology 1986;90:206-210.
23 Sato S, Inaba H, Oana S, et al: A case of primary biliary cirrhosis with mitochondrial encephalomyopathy. Nippon Shokakibyo Gakkai Zasshi 2005;102:595-599.

24 Illa I, Graus F, Ferrer I, Enríquez J: Sensory neuropathy as the initial manifestation of primary biliary cirrhosis. J Neurol Neurosurg Psychiatry 1989;52:1307.

25 Escalante S, Arpa J, Sebastián de la Cruz F, Santiago S: Neuropatía sensitiva en la cirrosis biliar primaria. Neurología 2002:17:651-653.

26 Posner JB: Paraneoplastic syndromes; in Bradley WG, Daroff RB, Fenichel GM, Marsden CD (eds): Neurology in the Clinical Practice, ed 3. London, Butterworth-Heinemann, 2000, chapt 58, sect F, pp 1299-1307.

27 Nakamura H, Tokonami F, Yamasaki M: Hashimoto's encephalopathy. Case report and diagnostic issues in Japan. Rinsho Shinkeigaku 2002;42:162-166

28 Magy L, Vallat JM: Hashimoto's encephalitis. Rev Neurol (Paris) 2002;158:966-970.

29 Zambrana JL, Fuentes F, Rosa F, Velasco MJ: Hashimoto's disease presenting as encephalitis in a young woman. Am J Med 2002;112: 163-164.

30 Sunil GS, Mariash CN: Hashimoto's encephalitis. J Clin Endocrinol Metab 2001;86:947.

31 Nakajima A, Yukitake M, Nagaishi A, et al: An autopsied case of limbic encephalitis associated with extremely high titers of anti-SS-A antibodies in serum and antineuronal antibodies in CSF. Rinsho Shinkeigaku 2005;45: 100-104.

32 Stubgen JP: Nervous system lupus mimics limbic encephalitis. Lupus 1998;7:557-560.

33 Mori M, Kuwabara S, Yoshiyama M, Kanesaka T, Ogata T, Hattori T: Successful immune treatment for non-paraneoplastic limbic encephalitis. J Neurol Sci 2002;201:85-88. 